Arhe XVI, 32/2019

UDK 1:331

DOI https://doi.org/10.19090/arhe.2019.32.169-197

Originalni naučni rad

Original Scientific Article

NEMANJA MIĆIĆ ${ }^{1}$

Univerzitet u Novom Sadu, Filozofski fakultet

\title{
PRIČA FILOZOFIJE PRIČA KAO RAD FILOZOFIJE I FILOZOFIJA RADA (FILOZOFIJE): OGLEDI O NARATIVNOM METODU KAO RADU JEZIKA U SVETLU DUHOVNOG ŽIVOTINJSKOG
} CARSTVA IZ HEGELOVE FENOMENOLOGIJE DUHA (II DEO)

Sažetak: U ovim ogledima ćemo pokušati da, putem priče filozofije priča, pokažemo nešto drugačiji ugao posmatranja filozofije rada (filozofije), koja se može iščitati iz Hegelovog odeljka Duhovno životinjsko carstvo $i$ obmana ili sama stvar, iz Fenomenologije duha. Umesto praćenja uobičajenih tekstova, koji na ovaj Hegelov narativ reaguju tumačeći ga iz vizure opisa intelektualnog ili akademskog rada i angažovanja, ili pak rada uopšte, sa naše strane bismo želeli najpre da pokažemo da je svaka delatnost u prvom redu jezičko-pripovesna, kao i da su rezultati rada jezika uvek neke (kontingentne) priče. One svoju aktualizaciju imaju samo putem neprestanog odnošenja sa drugim pričama, u čistom narativnom mnoštvu, koje jezik fundamentalno manifestuje. Ukoliko ima bilo kakvog rada i delatnosti, ono je jezičko-narativno. Videćemo koliko nam Hegelova studija i njen spekulativni karakter može pomoći ili odmoći u pokušaju kristalisanja te priče filozofije priča, kao filozofije rada (filozofije).

Ključne reči: narativ, priča, mnoštvo, kontingencija, rad, filozofija, delanje, Hegel, duhovno životinjsko carstvo

${ }^{1}$ E-mail adresa autora: nemanja.micic@ff.uns.ac.rs 


\section{POJAM INDIVIDUALITETA KAO REALNOG}

Govoreći o nemogućnosti ograničenja bića da ograniči i delanje svesti, Hegel pokazuje još jednu suptilnu naznaku pripovesnog mnoštva: „Pa ipak ovo ograničenje bića nije u stanju da ograniči delanje svesti, jer to delanje svesti jeste ovde jedno savršeno povezivanje sa samim sobom; ukinuta je veza sa drugim koja bi predstavljala njegovo ograničenje“. ${ }^{2}$ To podrazumeva da ograničenje datog narativnog čvorišta, ili pak narativne konstelacije, nije u stanju da ograniči delanje drugih pripovesti, čvorišta, mreža, horizonata, niti da spreči pokazivanje čistog narativnog mnoštva. Međutim, kako shvatiti tu „vezu sa drugim“? Da li je ona veza sa drugim pričama? To može biti tako uzeto samo dok se uvek pretpostavlja jedinstvo toka svesti, koje upravlja spletom priča određenog individualiteta. Međutim, svest nije od ovih priča nezavisna, nije nešto što samo prati ove priče; ona može biti jedino same te priče, kojima je opet, sa svoje strane, nemoguće nametnuti to da ekskluzivno pripadaju nekoj subjektivnosti. Sve one su, u prvom redu, priče jezika i konstelacija, mreža koje se na takav način (krajnje kontingentno) pletu. Priče su u stanju da ograničavaju priče, odnosno da pruže ili uskrate slobodu drugim pričama - to je način na koji bi možda pre trebalo posmatrati ove pojmove ograničenja, mada je jasno da je i to prvenstveno tema raznolikih priča, kao povod koji jezik daje samom sebi za dalji rad i generisanje čistog pripovesnog mnoštva. Jezik(-)priče vrše ovo „udahnjivanje“, kao i svako tvorenje konkretnih pojedinačnosti - van priča i jezika nemamo „životinjskog života“, „udahnjivanja daha“, „vode“, „vazduha“, „zemlje“, i dr.: „Kao što neodređeni životinjski život udahnjuje svoj dah, recimo, elementu vode, vazduha ili zemlje, i unutar zemlje opet određenijim principima, utapajući u njih sve svoje momente, ali ne obazirući se na ovo ograničenje elementa te svoje momente održava u svojoj vlasti i sebe u svome jednome, pa kao ta naročita organizacija ostaje isti opšti životinjski život". 3

\footnotetext{
${ }^{2}$ Hegel, G. V. F., Fenomenologija duha, BIGZ, Beograd 1986. (prev. Popović, Nikola M.), str. 234.

${ }^{3}$ Ibid.
} 
Svaki nagoveštaj toga kako priče prožimaju narativna čvorišta morao bi biti praćen uvidom da narativna čvorišta nisu odvojena od ovog tkiva priča, jer ono ne lebdi negde izvan i čeka svoje delatno postvarenje kroz čvorište kao individuum, već sam individuum jeste narativna konstrukcija.

Za nas nema ove naslućene podvojenosti pripovesnog horizonta od narativnog čvorišta: „Prosta, pak, iskonska priroda, nalazeći se u delanju i svesti o delanju, stupa u razliku koja pripada tome delanju. Kao predmet, i to kao predmet koji još pripada svesti, to delanje postoji pre svega kao svrha, i prema tome je suprotno svakoj postojećoj stvarnosti““. Međutim, da li ovo „suprotno“ možemo čitati zapravo kao „drugo“, ukoliko je „postojeća stvarnost“ onaj pripovesni horizont (koji nikada nije kao takav dat, pružen, jer bi se na taj način ponavljala pripovesna matrica metafizičkog govora, po kojoj je bitak prezentnost, a ne neprekidni proces postajanja) iz kojeg određeni narativi, skupljeni u narativno čvorište, crpe materijal za dalju jezičku deskripciju i redeskripciju? Bilo kako bilo, krajnje simptomatično i uočljivo je to da se ova priča o filozofiji priča snalazi i pronalazi sa narativom spekulativne filozofije na način da se oni nedvosmisleno nadopunjuju. Ovde imamo nešto što se može tumačiti upravo kao momenat razilaska od bitka kao prezentnosti, ukočenosti, jer Hegel kaže: „Drugi je momenat kretanje svrhe, koja se zamišlja kao mirujuća, ostvarenje kao vezivanje svrhe sa potpuno formalnom stvarnošću, a time predstavljanje samog prelaženja ili sredstvo".5 Drugim rečima, jedino na osnovu datog pripovesnog horizonta, obojenog metafizičkim govorom, ovo kretanje svrhe se može zamisliti kao mirujuće. ${ }^{6}$ Odmah potom imamo i treći momenat, koji ovo neprestano postajanje nečega drugog, kao uvek drugog narativa, potvrđuje: „Naposletku, treći momenat jeste predmet, koji nije više ona svrha, koje je ono što dela neposredno svesno kao svoje svrhe, već koji

\footnotetext{
${ }^{4}$ Ibid., str. 235.

${ }^{5}$ Ibid.

${ }^{6}$ Ipak, kako tada uspostaviti diferenciju između ovog „Zamišljanja“ i nekog „postvarenja“, imajući u vidu narativ filozofije priča? Koliko god da je Hegel zaista krajnje oprezan, jezik je nemilosrdan u pokušaju pokazivanja čistog mnoštva.
} 
izvan toga delanja i za njega postoji kao nešto drugo“. ${ }^{7}$ To ne znači da priče gube na svojoj konzistenciji. Predlog za to kako one održavaju tu stalnost, uprkos neprestanoj razlici (koja se istovremeno proglašava i ukida?), može glasiti ovako:

„Ove različite strane moraju se, međutim, shodno pojmu te sfere, zadržati tako da sadržina koja se nalazi u njima, ostane ista i da u njih ne uđe nikakva razlika, ni razlika između individualiteta i bića uopšte, niti razlika između svrhe i individualiteta kao iskonske prirode, niti između svrhe i postojeće stvarnosti, isto tako ni razlika između sredstava i stvarnosti kao apsolutne svrhe, niti razlika proizvedene stvarnosti od svrhe ili iskonske prirode ili sredstva“. ${ }^{8}$

Da li iskonski određena priroda individualiteta nije u prvom redu delatna, jer na neki način mora postojati određena „podloga“ za distingviranje i vrednovanje kategorija talenta, sposobnosti, karaktera? „Na prvom mestu, dakle, iskonski određena priroda individualiteta, njegova neposredna suština još nije postavljena kao suština koja dela, i tako se označuje kao naročita sposobnost, kao talenat, karakter, itd.“. ${ }^{9} \mathrm{Da}$ li ovo možemo pak uputiti na priču o, fukoovski rečeno, „dispozitivu“ jezika i njegove heterogenosti, ne bismo li se sačuvali od asocijacija na zalog romantizma, koji u određenoj meri slavi svojevrsni elitizam i stalnost, postojanost kategorija nadarenosti, sposobnosti, talenta? Za Fukoa i rečeno i nerečeno bivaju elementi dispozitiva, koji je za nas dispozitiv jezika, njegovih priča, da svoja postvarenja potraži na mnogostruke načine. Ako ima onog delatnog momenta jezika, on je uvek narativan, dok „naročitu sposobnost“, „talenat" i „karakter“" pripisujemo jezičko-pripovesnoj skupini koja vrši te vrste distinkcija. Te kategorije nisu izolovane, ne stoje van priča i ne mogu se posmatrati i uzimati izvan horizonta koji ih donosi. O „talentu“ u ovom smislu se može govoriti samo kao o dispozitivu narativnog horizonta, ,predispoziciji“ da dalje pričama-jeziku predaje vlastite sadržaje i građe, za mogućnost drugih

\footnotetext{
${ }^{7}$ Hegel, G. V. F., Fenomenologija duha, BIGZ, Beograd, 1986. (prev. Popović, Nikola M.), str. 233.

${ }^{8}$ Ibid, str. 235.

${ }^{9}$ Ibid.
} 
deskripcija i redeskripcija. „Talenat", „nadarenost“", „karakter“ nisu transnarativne kategorije, koje su prisutne, važeće i vrednovane u svim pripovesnim konstelacijama na jednak način. „Usavršavanje“, koje se u nastavku pominje, mi vidimo kao prepoznavanje ovih neprestanih redeskripcija i deskripcija koje jezik, pričajući priče, izvršava:

„Osim toga, ta iskonska suština nije samo sadržina svrhe, već predstavlja po sebi takođe stvarnost koja se inače pojavljuje kao dati materijal delanja, kao nađena stvarnost i stvarnost koju u delanju treba usavršiti. Delanje se, naime, sastoji jedino u potpunom prevođenju iz forme bića, koje još nije prikazano, u formu prikazanoga bića; biće po sebi one stvarnosti koja je protivstavljena svesti srozalo se na čist prazan privid“..$^{10}$

Iz ovoga se, takođe, da iščitati i poziv na rad kreativne redeskripcije postojećih vokabulara, iz datog mnoštva. Jedino što tada više ne bismo govorili da to čini neka svest, već pre svega priče(-)jezik, koji i omogućuju ovakav narativ o slobodarskom duhu, koji uvek vidi dalje od „postojeće stvarnosti“ - taj pogled je pak uvek usmeren ka horizontu priča, a ako postoji odluka na delanje, ona je isprva motivisana nemogućnošću da se sve misli, kaže, ispriča jednim narativom, koliko god dominantan i autoritativan on bio. Ovo su Hegelove slutnje „pukotina“ na i $u$ pričama, nemogućnosti njihovih konačnih završenosti, zaokruženosti, celovitosti i nenadopunjivosti: „Ta svest odlučujući se na delanje ne dozvoljava, dakle, da je zavede privid postojeće stvarnosti““. ${ }^{11}$ Drugačije rečeno, jezik je uvek spreman i u stanju pripravnosti za dalje (re)deskripcije onoga što mu je pripovesnom jezičkom predajom dato, pre-dato. ,[I] isto tako ona mora da se oslobodi lutanja po praznim mislima i svrhama, pa da se čvrsto veže za iskonsku sadržinu svoje suštine“. ${ }^{12}$ Delanje je postajanje duha kao svesti. Ovu „stvarnost“ bi najpre trebalo ovde uzeti kao (s)nalaženje u ne samo sedimentiranoj, već i dominantnoj pripovesnoj konstelaciji, koja određuje većinu smerova daljih jezičko-narativnih pojavljivanja. Priča ne može znati kakva će biti

\footnotetext{
${ }^{10}$ Ibid.

11 Ibid.

12 Ibid.
} 
pre nego što se jezikom i predajom narativno-jezičkih okolnosti desila (setimo se da je „sama stvar“ određena tek u retrospektivi), pripadala ona svojom sadržinom pominjanim dominantnim konstelacijama ili ne. Što se tiče svrhe delanja, ona se ne pronalazi nigde nezavisno od postavljanja takvog „zahteva“, koji propisuje, nudi ili pak preporučuje pripovesna mreža, kao do-nosilac daljih priča. Svrha nije nikakav otrgnuti entitet, kao ni bilo koja druga tema priča. Narativi „odlučuju“ o sopstvenim kretanjima kroz međusobna odmeravanja sa drugim narativima i njihovim konstelacijama. Ishodi tih igara su krajnje nepredvidivi, zbog toga je učitavanje i pretpostavljanje bilo kakve nezavisne pozicije neprimereno. „Individuum koji pristupa delanju“ može stoga biti upućen isključivo na sâmo jezičko-pripovesno događanje, koje pak ne ulazi već je uvek prisutno u tom obliku, ukoliko se bilo kako raspoznaje. To delanje se ne zaustavlja na „krugu“, već, ako želimo da se služimo asocijacijama tog tipa (koje upućuju ni na šta drugo do na dalje priče), njemu pre pripadaju „Lanci Markova“, „Mandelbrotov skup“, itd. Delanje nije nikada određeno ranije pretpostavljenom svrhom, zato što to delanje čeka na ozbiljnost uvažavanja kontingencije jezičkih pojavljivanja. Priče ,ne započinju“ niti posredno niti neposredno, jer one i ne otpočinju, njihov rad je rad jezika, a rezultat te delatnosti uvek priče, kojima svakako ne možemo pripisati bilo kakav predumišljaj početka, sredstva ili svrhe.

„Stoga individuum ne može znati šta on jeste pre nego što se delanjem ostvario“ “ ${ }^{13}$ Priča ne može znati šta ona jeste pre nego što se jezikom-pripovešću ostvarila. To ostvarenje je rezultat rada priče-jezika. „A time izgleda da individuum nije u stanju da odredi svrhu svoga delanja pre no što je delao“. ${ }^{14}$ Priča nije u stanju da odredi sopstvenu svrhu, pre nego što je sama postavi, zato što svrhu ne dobija nekakvom transcendencijom, već jezičko-pripovesnom raspodelom koja na postojanju ili nepostojanju svrhe insistira, gradi svoj zaplet tematizujući je, ili pak ne obraćajući pažnju na tu temu. „[A]li u isto vreme individuum, pošto on jeste svest, mora prethodno da ima pred sobom

\footnotetext{
${ }^{13}$ Ibid, str. 236.

${ }^{14}$ Ibid.
} 
radnju kao potpuno svoju, to jest kao svrhu“. ${ }^{15}$ Priče su u međusobnom prožimanju, gde bi, u ovom slučaju, ponovo ona konstelacija sa temom svrhe bila među dominantnijim. „Dakle, izgleda da se individuum koji pristupa delanju nalazi u jednome krugu, u kojem svaki momenat već pretpostavlja drugi momenat $[\ldots]^{\text {“", }}$ - ovde se naslućuje i pomenuta razmena priča, koja se upravo događa - ,[...] i da time ne može da nađe neki početak [...]“ - zato što, kao što je rečeno, narativi nemaju ovaj početak - , ,...] jer on tek na osnovu svoga dela upoznaje svoju iskonsku suštinu, koja mora da bude njegova svrha, a da bi delao, mora prethodno da ima svrhu“. ${ }^{16} \mathrm{Tu}$ suštinu određuje na osnovu narativa, koji tu temu isporučuje i favorizuje. „Ali upravo zbog toga individuum mora da započne neposredno, i da pristupi delatnosti pod bilo kojim okolnostima, bez daljeg razmišljanja o početku, sredstvu i svrsi; jer njegova suština i njegova po sebi postojeća priroda jesu sve ujedno - početak, sredstvo i svrha“. ${ }^{17}$ To „neposredno započinjanje“ se ne može dešavati nikako drugačije nego pripovesno-jezički. Zbog toga moramo neprestano izvršavati ovu svojevrsnu „dekonstrukciju“ narativnim metodom, kako onoga što imamo pre, tako i onoga što sledi u nastavku. Na svaku vrstu tendencioznog govora o različitim temama, poput one o talentu kao iskonskom individualitetu, kao ,prelaženju svrhe u stvarnost“, možemo postavljati pitanja poput „koju stvarnost?“”, ili „koji individualitet?“. Međutim, zahtevati da odgovor na to pitanje bude „pripovesnu““/pripovesni“, jer priče i pružaju ove konstelacije u kojima se zahtevaju izvršenja dinamike pitanja i odgovora, takođe se može opisati kao tendenciozan.

„Kao početak delatnost se nalazi u okolnostima delanja: i interesovanje koje individuum ima za nešto jeste već dati odgovor na pitanje: da li i šta tu treba raditi““. ${ }^{18}$ Ovo zvuči kao još jedan u nizu elemenata koji bi bio u izvesnoj meri kompatibilan sa filozofijom priča: ako se može govoriti o bilo kakvom početku priča, one uvek iskrsavaju

\footnotetext{
${ }^{15}$ Ibid.

${ }^{16}$ Ibid.

${ }^{17}$ Ibid.

${ }^{18}$ Ibid., str. 236.
} 
kao određeni momenti pripovesno-jezičkih okolnosti, a interesovanje priča za generisanje daljih sadržaja je već pretpostavljeno samim narativno-delatnim događanjem. Zbog toga je krajnje suvišno pitati o tome „treba li pričati?“, jer pričanje uvek jeste, što pokazuje i nemogućnost postavljanja samog tog pitanja bez pripovesnog horizonta koji tu zapitanost proizvodi. Priča je ona delatnost o kojoj se račun ne može položiti ni na koji način drugačije nego pripovesnim radom. Šta su drugo okolnosti, nego jezik-priče? „Nema ničeg izvan priča“ - a to nam nudi kao temu jedan takođe kontingentni i nepoopštivi narativ, što znači da se ne može nikako raditi o iskazu koji bi stajao nezavisno od ove, konkretne, priče (kao priče o filozofiji priča). Istovremeno, jasno je da narativi imaju interesovanje za druge narative. Ovo ,interesovanje individuuma“" je ništa drugo do zainteresovanost mnoštva priča nekog narativnog čvorišta za nastavljanje rada jezika kroz dalje pripovesti. Na tu zainteresovanost se načelno mora računati, iako ona svakako može izostati; ali da te zainteresovanosti uglavnom ima svedoči nam to što ima narativnog mnoštva. Izvesno je da nisu sve priče jednako zainteresovane za druge, ali su ovi ulasci u različite odnose, odmeravanja i koalicije, koje mogu dovesti do konstelacija, nepredvidivi i kontingentni.

Polifoniju različitih glasova/priča možemo iščitati i u ovim pronicljivim i jedva primetnim odrednicama, po kojima zatečena stvarnost izgleda da nešto jeste, te ona ,predstavlja po sebi njegovu iskonsku prirodu koja ima samo izgled jednog bića“. ${ }^{19}$

„Ono, dakle, što postoji jesu zatečene okolnosti koje po sebi jesu iskonska priroda individuuma; potom interesovanje koje on postavlja upravo kao ono što je njegovo ili kao svrhu; naposletku spajanje i ukidanje te suprotnosti u sredstvu. To spajanje spada takođe još unutar svesti, i celina koju smo maločas posmatrali predstavlja jednu stranu jedne suprotnosti. Sâmo prelaženje ili sredstvo ukida ovaj još preostali privid suprotstavljanja; - jer ono je jedinstvo spoljašnjega i unutrašnjega, suprotnost određenosti, koje poseduje kao unutrašnje sredstvo; ono, dakle, ukida to suprotstavljanje i postavlja sebe, to jedinstvo delanja $i$ bića, isto tako kao ono što je spoljašnje kao i

\footnotetext{
${ }^{19}$ Ibid., kurziv naš.
} 
individualitet koji je postao stvarnim, to jest koji je postavljen za sebe sama kao ono što bivstvuje. Na taj način celokupna radnja ne istupa iz sebe ni kao okolnosti, niti kao svrha, niti sredstvo, niti kao tvorevina““. ${ }^{20}$

„Zatečene okolnosti“" su narativne konstelacije, čiji jezik se predaje dalje kroz narativna čvorišta nazvana „individuumima“. Ovo „njegovo“ je prisvojna zamenica koja se može odnositi jedino na priču, koja bi, sa svoje strane, već trebalo da je pluralia tantum. Interesovanje se, za Hegela, samo postavlja kao nešto što pripada individuumu, narativnom čvorištu odvojenom od narativne konstelacije. Da tog striktnog odvajanja ne može biti svedoči nam navod o spajanju i ukidanju te suprotnosti, koja se za njega dešava unutar svesti. Rečeno je već u više navrata da tu svest mi moramo razumeti kao momente narativa, koji tu priču isporučuju na takav način, među drugim pričama $u$ njihovom čistom mnoštvu. Ipak, ovog čitavog izraza može biti samo na osnovu narativa koji jeziku pre-daju ovakve priče, kao i bilo koje druge. Ovo podsećanje smatramo krucijalnim da bi se kontingencija mogla dovoljno apostrofirati i radikalizovati. Ukoliko tvorevina uvek jeste narativ, onda se sa ovim valja saglasiti, jer upućuje na fundamentalnu različitost priča, koje nikada nisu iste: „Ali, sa tvorevinom nastupa, kako izgleda, razlika iskonskih priroda; tvorevina je nešto što je određeno, kao i iskonska priroda koju ona izražava; jer na tvorevini, otpuštenoj od delanja kao bivstvujuća stvarnost, nalazi se negativitet kao kvalitet". ${ }^{21}$ Time što one nisu iste, događa se ovo odmeravanje narativa - ono se ne dešava za neku svest, koja bi njima prethodila i koja je opšta:

„Svest pak određuje sebe, nasuprot tvorevini, kao ono što u sebi ima određenost kao negativitet uopšte, kao delanje; svest je, dakle, ono što je opšte nausprot onoj određenosti tvorevine; ona dakle može da uporedi tu tvorevinu sa drugim tvorevinama i da na osnovu toga shvati same individualitete kao različite, a individuum koji u svojoj tvorevini zakoračava dalje ili kao snažniju energiju volje ili kao bogatiju prirodu, to jest kao takvu, čija je iskonska određenost manje

\footnotetext{
${ }^{20}$ Ibid., str. 236-237.

${ }^{21}$ Ibid., str. 237.
} 
ograničena, a neku drugu prirodu naprotiv kao neku slabiju i siromašniju“". ${ }^{22}$

Ovakva upoređivanja (koja su uvek jezičko-pripovesna) vrše narativi međusobno, a nikada svest koja bi eventualno stajala van priča. Jezik ne može sebe (isključivo) određivati, ako želi da bude veran svom autentičnijem zahvatanju, kroz priču o svesti koja bi bila nešto opšte, vannarativno, nasuprot određenosti tvorevine. Gde se nalazi ta „određenost tvorevine“, koja više ne bi imala da zahvali svoje pojavljivanje i stupanje na scenu svom (dakako neprepoznatom) uslovu mogućnosti, koji je priča? Međutim, ako bi se jedan deo ovog rada narativnog metoda mogao podvesti pod pokušaje razgradnje (Abbau), svojevrsnog demaskiranja fundamentalne zavisnosti Hegelove (ili bilo koje druge) terminološke građevine od priča, onda bi naredni korak podrazumevao i pružanje apologije toj priči. Jer, čemu i za šta je pripremljeno to demaskiranje? Ono je na jednak način pripovesna građa, koja je ponuđena jeziku, odnosno, drugim narativima, da nastave pokazivanje njihovog čistog mnoštva. Ova, kao i svaka druga priča uostalom, u znaku su kontingencije - barem tako su one posložene u ovoj priči. Njeno dalje generisanje ili pak zaustavljanje kretanja, takođe je na raspolaganju jeziku, što pada u liniju sa narativom koji insistira na pomenutoj mnoštvenosti, kao i kontingenciji.

„Nasuprot ovoj nesuštinskoj razlici veličine, dobro i zlo izražavali bi jednu apsolutnu razliku; ali ta apsolutna razlika ovde ne postoji. Ono što bi se shvatilo na jedan ili drugi način jeste na isti način neko tvorenje i delanje, jedno prikazivanje i iskazivanje jednog individualiteta, i zbog toga je sve dobro; i zapravo se ne bi moglo reći šta bi moglo biti ono što je zlo““. ${ }^{23}$ Taj individualitet je za nas u ovom slučaju priča. Narativi su ti koje vrše pomenute procene različitosti „individualiteta“, koji su ništa drugo nego narativna čvorišta. Tvorevine tih čvorišta su priče, ponuđene dalje jeziku na igre deskripcija i redeskripcija. „Snažnija energija volje“, „bogatija priroda“, „manja ograničenost iskonske određenosti“, ili „slabost i siromašnost“" su ništa

\footnotetext{
${ }^{22}$ Ibid.

${ }^{23}$ Ibid.
} 
drugo do svedočanstva priča o pričama. U svetlu jedne konstelacije, određena narativna skupina se može reflektovati kao prozaična i osiromašena, što ne znači da se tu završava svaka dalja procena relevantnosti i vrednosti te skupine. U drugim okolnostima i u drugačije posloženom narativnom univerzumu, ta „slabost" može figurirati ne samo kao potpuniji i relevantniji izraz, već možda ta tema uopšte ne biva problematizovana, usled okolnosti koje još uvek ne zahtevaju takav razvoj priče, niti se taj zahtev uopšte tada eventualno može naslućivati. Filozofija priča, odnosno, priča o njoj, predlaže stajalište s one strane ovog i ovakvog procesuiranja „,dobrog“ i „lošeg“, kao datih izvan narativnih okolnosti koje te priče (o „dobrom“ i „lošem“) nude na takav način, te predlažu binarnu, monohromatsku tabelarnost, unutar koje bi se, na osnovu kvazi-objektivnih ili apsolutnih kriterijuma, narativi žigosali na ovaj ili onaj način. U ovom trenutku za nas deluje daleko važnijim zadatkom prepoznati fundamentalnu narativnost svakog jezičkog događanja, kao i kontingenciju generisanja priča $u$ tom čistom narativnom mnoštvu, nego posezanje za jednoličnim narativnim formama koje, upravo usled nemogućnosti ili nespremnosti ovog samoreflektovanja vlastitosti kao pripovesno-jezičke, ostaju zarobljene u pojedinostima sopstvenih proizvoda i proizvođenja, smatrajući te sadržaje i priče koje nastaju na tom tragu, jedino vrednim. Bahtinovski rečeno, jezik govor o monologizmu i dijalogizmu, kao svojim karakteristikama, zadužuje od naslova tih priča. Razumemo li ponovo ovaj individualitet kao priče, odnosno, pripovesno čvorište, uočavamo neporecivu bliskost naše filozofije priča, sa ovim Hegelovim pisanjem. Za jezik(-)priče ne postoji ništa što one same nisu proizvele, što jednako znači i da su svaka „stvarnost“, kao, uostalom i ,iluzija“, proizvodi rada tih pripovesnojezičkih sila. Ovde se saglašavamo ne samo sa konstatacijom da se ne bi moglo (ukoliko zaista na ovakav način shvatimo individualitet, kao čvorište mnoštva priča) izvestiti o bilo kakvoj razlici „nestvarnog“ i „stvarnog“ tvorenja, već i predlogom daljeg postupanja, koje bi upućivalo na neprestano upoređivanje tih momenata. Taj predlog bi omogućio konstantno „držanje“ priče o filozofiji priča uz ostale priče, odnosno, reflektivni gest kojim bi bilo nemoguće i neizvodljivo održavanje monologa jednog narativa ili jedne konstelacije, tako da se tim 
monologizmom sputaju i uguše glasovi onog čistog mnoštva za koje smo pokazali da se svuda manifestuje, pa čak i u tim autoritarnim narativima, koji ne ostavljaju gotovo nimalo prostora za dijalog. Ako se neki monolog odvija, on se može odvijati samo kao „monolog jezika sa samim sobom“, ali opet tako da se ta monološka dimenzija shvati krajnje uslovno rečeno - jer jezik na svakom koraku nudi različite priče, tj. biva ponuđen istim tim pričama za dalja pojavljivanja. Priče i njihove mreže su stoga u neprestanim dijalozima. Rad filozofije priče, kao svojevrsni narativni metod, pokazuje da je između „noći mogućnosti““ i „dana prisutnosti ${ }^{\text {‘62 }}$ neprimereno određivati ili povlačiti bilo kakvu granicu; ali ona je svakako moguća, iako samo na osnovu narativne konstelacije koja tu distinkciju stavlja u pogon i favorizuje.

\section{SAMA STVAR I INDIVIDUALITET}

Razmotrimo na koji način jezik preduzima na sebe ovo neprestano pokazivanje i delovanje mnoštva pripovesti/glasova:

„U tome se sastoji pojam koji stvara o sebi ona svest koja ima izvesnosti o sebi kao apsolutnom prožimanju individualiteta i bića; pogledajmo da li iskustvo potvrđuje svesti taj pojam i da li se njegov realitet slaže sa tim. Tvorevina je realitet koji svest daje sebi; ona predstavlja ono u čemu individuum jeste za nju [...] u tvorevini uopšte individuum je izašao i postavio se u elemenat opštosti, u bezodredbeni prostor bića“. 25

Ovaj pojam iskustva za nas, u datoj narativnoj postavci, koja insistira na priči o filozofiji priča, na prvi pogled deluje krajnje neuhvatljivo. Bilo da Hegel dolazi do potvrdnog ili odričnog odgovora na ovo pitanje, za nas sama mogućnost tako postavljenog pitanja ne bi trebalo da ostane neproblematizovana. Uostalom, problematizovanje ne bi valjalo da zaobiđe ni ovo razumevanje tvorevine kao „realiteta koji svest daje sebi“, jer se ova odvojenost tvorevine i individualiteta ne sme naprosto prihvatiti i usvojiti - iako, po Hegelovom nacrtu, možemo

\footnotetext{
${ }^{24}$ Up. Ibid.

${ }^{25}$ Ibid., str. 238.
} 
izvesti priču o tvorevini koja prvenstveno može biti priča koju jezik, na takav način, predaje drugim pričama. Ali, nadalje, ovo „sebi“ tada može biti rečeno samo uslovno i pod velikim ,ako“, pošto moramo neprestano upućivati na onaj rad razlike, kojim se tvori uvek druga/drugačija priča. To znači da se tvorevina ne može predavati „sebi“ u strogom smislu, već mnoštvu narativa, iako ta tvorevina odatle jedino i može poticati. Ali, čujmo još neki glas: istovremeno, iskustvo koje bi potvrđivalo svesti pojam koji ona stvara o sebi, moglo bi se uzeti i kao uzajamni odnos, osobeno „razmenjivanje pogleda“, koje narativni horizont i priča zajedno iniciraju samim činom dijaloške razmene, kojom uranjaju u jezičko tkivo jedno drugog! Na taj način, (pripovesna) tvorevina se zaista ispostavlja kao ništa drugo do „realitet“ (događanje ovog odnošenja) koji (narativna) svest daje sebi. Sada vidimo kako jezik inicira ovo neprestano pokazivanje i delovanje mnoštva pripovesti/glasova.

„Svest koja se povlači iz svoje tvorevine jeste u stvari opšta svest - jer se ona u toj suprotnosti pretvara u apsolutni negativitet ili u delo nasuprot svojoj tvorevini koja je posebna svest; ona dakle prevazilazi sebe kao tvorevinu, i sama jeste bezodredbeni prostor, koji ne smatra da ga njena tvorevina ispunjava“. ${ }^{26}$ Ovo može biti jedan vid opisa momenata odnošenja onoga što razumevamo pod narativnom konstelacijom i narativnim čvorištem, iako ovog odnošenja u strogom smislu za nas ne može biti; a to se može uzeti, takođe, i kao momenat konvergiranja, usaglašavanja priča o filozofiji priča i Hegelovog narativa. Podvlačimo da se radi o samo jednom vidu opisa zato što većinom i uglavnom izbegavamo da priču o filozofiji priča pripovedamo naprosto ponavljajući matricu nasleđenih narativa. U ovom slučaju bi se zahtevalo da se o „povlačenju svesti iz svoje tvorevine“ govori u prvom redu kao prepoznavanju vlastite kontingentnosti neke priče, te razumevanja da je dati sadržaj pušten na milost i nemilost drugim pričama. Možemo reći da ovim Hegel nagoveštava to da priče nemaju sebe u posedu u jednom obliku ili formi, već da je njihova nestalnost i nepostojanost nešto na šta se mora ozbiljno računati - ne kao na usud ili zlu kob, već kao šansu, priliku za prevazilaženje svakog vida autoritarnosti i despotizma nekog

${ }^{26}$ Ibid. 
narativnog polja, kao i za pokazivanje čistog narativnog mnoštva, polifonije pripovesnih glasova. Priča je priča za sebe, kontingentna i nepoopštiva: „Pre svega treba nastalu tvorevinu razmatrati za sebe“. ${ }^{27}$

Kada se navodi da: „Tvorevina postoji, to jest ona postoji za druge individualitete $[\ldots]]^{\text {“, }}{ }^{28}$ ti drugi individualiteti, kao i sama tvorevina su narativi; ,[... ] i za njih je neka tuđa stvarnost na čije mesto oni moraju postaviti svoju stvarnost $[\ldots]^{\text {“ }}{ }^{29}$ gde prisvojna zamenica mora stajati na mestu priča, odnosno, onaj pripovesni sloj koji je u blizini i jednako konstitutivan, konstituišući za datu „stvarnost“; ,[...] da bi svojim delanjem dali sebi svest o svome jedinstvu sa stvarnošću [...] “, ${ }^{30}$ gde stapanje upućuje na stapanje narativa; ,[...] ili njihovo interesovanje za tu tvorevinu koje je postavila njihova iskonska priroda jeste neko drukčije interesovanje nego što je vlastito interesovanje te tvorevine, koja je time pretvorena u nešto drugo“. ${ }^{31}$ To „drugo“ je narativ prepričan ili ispričan uvek drugom, odnosno, nikada do kraja istom pričom. „Tvorevina je, dakle, uopšte nešto prolazno, koje se blagodareći suprotnosti drugih sila i interesa gasi i realitet individualiteta prikazuje pre kao iščezavajući nego kao izvršen“. ${ }^{32}$ Sve ovo može za naš narativ figurirati kao par excellence primer načina odnošenja narativa i konstelacija koje oni prave, putem raznolikih koalicija, kao i eventualni primer načina odabira, smena, pulsacija prihvatanja i odbacivanja koje priče vrše u procesu spajanja sa drugim pričama. Produkt tog događanja su i redovi koje upravo ispisujemo, te kao takvi potvrđuju rad jezika(-)priča i njihove čiste mnoštvenosti.

Dalje, da li se „pojam“ i „realitet“ uzimaju kao međusobno „razmenljivi“? (,iskonska priroda“"?), iako svest to doživljava kao nesaglasnost, putem tvorevine? „Međutim, čisto delanje jeste forma ravna samoj sebi, kojoj je sa time određenost iskonske prirode nejednaka“ ${ }^{33} \mathrm{Da}$

\footnotetext{
${ }^{27}$ Ibid.

${ }^{28}$ Ibid., str. 239.

${ }^{29}$ Ibid.

${ }^{30}$ Ibid.

${ }^{31}$ Ibid.

32 Ibid.

${ }^{33}$ Ibid, str. 239.
} 
li bi se moglo reći da se ovim sugeriše svojevrsno ukidanje razlike između označenog (pojam) i označitelja (zvuk, slika, ,realitet“)?

„Kao drugde, tako je i ovde svejedno šta se od toga dvoga zove pojam a šta realitet; iskonska je priroda ono što je zamišljeno ili ono po-sebi, nasuprot tvorenju u kojem tek ona poseduje svoj realitet; ili iskonska priroda je biće ne samo individualiteta kao takvog, već i individualiteta kao tvorevine, dok je delanje iskonski pojam kao apsolutno prelaženje ili kao postajanje. Ovu nesaglasnost pojma sa realitetom koja leži u njegovoj suštini svest doživljuje u svojoj tvorevini, dakle, svest postaje onakvom kakva je uistinu, i njen prazni pojam iščezava sam od sebe“. ${ }^{34}$

Ono što se kod Hegela zapravo događa po ovom pitanju jeste ne samo proglašavanje te veze arbitrarnom, već nesuštinskom: „, [S]a jedne strane bi bilo idealno i transcendentalno označeno, u potpunosti prisutno za svest bez posrednika; sa druge površni označitelj, lišen bilo kakve označavajuće funkcije, nema materijalna prisutnost"“. ${ }^{35}$ Istovremeno, jasno je da za Hegela apsolutni duh u svom kretanju može biti označitelj koji „pruža“ značenje, putem označiteljske aktivnosti (koje to kretanje jeste) - ali ova pomenuta razmenljivost je još uočljivija u trenutku kada apsolutni duh dostigne svoje ispunjenje, bivajući označeno-označitelj i označitelj-označeno. ${ }^{36}$

U svakom slučaju, naznaka kontingencije bi se u ovom svetlu dala tematizovati kroz svojevrsnu „kontingenciju nužnosti“ i „nužnosti kontingencije“: „Nužnost tvorenja sastoji se u tome što je svrha prostonaprosto dovedena u vezu sa stvarnošću, i to jedinstvo jeste pojam tvorenja, dela se zato što delanje po sebi i za sebe predstavlja suštinu stvarnosti““. ${ }^{37}$ Dela se zato što jezičko-pripovesnog događanja i rasprostiranja ,ima“, a o toj evidentnosti se račun polaže nikako drugačije

\footnotetext{
${ }^{34}$ Ibid.

${ }^{35}$ Baugh, Bruce, French Hegel. From Surrealism to Postmodernism, Routledge, London and New York, 2003., str. 136-137.

${ }^{36}$ Up. Silverman, Hugh J., Inscriptions: After Phenomenology and Structuralism, Northwestern University Press, Evanston, 1997., str. 190.

${ }^{37}$ Hegel, G. V. F., Fenomenologija duha, BIGZ, Beograd, 1986. (prev. Popović, Nikola M.), str. 240.
} 
nego upravo narativno i jezički. „Stvarnost“ je uvek pripovesno-jezička, kao narativni konstrukt:

„Na taj se, dakle, način svest reflektira iz svoje prolazne tvorevine u sebe, i zadržava svoj pojam i svoju izvesnost kao ono što bivstvuje i što se ne menja, nasuprot iskustvu o slučajnosti tvorenja; svest u stvari iskustvom saznaje svoj pojam u kojem stvarnost predstavlja samo jedan momenat, nešto za nju, ne ono što postoji po sebi i za sebe; ona doživljuje stvarnost kao momenat koji iščezava, i stoga stvarnost važi za svest samo kao biće uopšte, čija opštost jeste sa tvorenjem jedno te isto". 38

Priča se može reflektovati iz svoje prolazne tvorevine na način da može zadržati svoj pojam i svoju izvesnost kao ono što bivstvuje i što se ne menja, nasuprot iskustvu o slučajnosti tvorenja; ali to iskustvo je takođe iskustvo pripovesne konstelacije ili priče sa kojom ona odlučuje da načini ovakvu vrstu spoja. Istovremeno, priča se može reflektovati iz svoje prolazne tvorevine na način da ne zadržava svoj pojam i svoju izvesnost kao ono što bivstvuje i što se ne menja - ona se može „reflektovati“ i kao neprolazna tvorevina, ako shvatimo da ovaj čin refleksije nije ništa drugo do kontingentni način raspodele jezika putem delatno-tvoračke aktivnosti priča. Nadalje, da priče mogu otići na bilo koju stranu, a da ne izgube ništa od svog pripovednog karaktera potvrđuje nam i to što možemo vršiti svakakve vrste nasilja nad narativima. Primera radi, ništa nas objektivno ne sprečava, da sklopimo priču po kojoj svest iskustvom ne saznaje svoj pojam, u kojem stvarnost nikako ne predstavlja samo jedan momenat, te da stvarnost ne važi za svest samo kao biće uopšte, već pojedinačno biće, gde opštost tada sa tvorenjem nikako ne može biti jedno te isto. Međutim, ovo „nasilje“, koje je samo prosta negacija ovog konkretnog narativnog sklopa, zapravo je krajnje neinventivan izraz jezika, koji drugom narativu pristupa preoblačeći ga u ruho koje je on za sebe već iskrojio. Upravo iz tog razloga se neretko demonstrira sva banalnost „anti-hegelijanskih“ narativa. „Misliti s one strane nekog pripovesnog horizonta" često sa sobom nosi i konstantno obraćanje pažnje na priče čiji se tokovi pokušavaju preusmeriti, što znači

${ }^{38}$ Ibid., str. 241. 
da one i dalje ostaju u neposrednoj blizini. Pripremiti novi teren i omogućiti radikalno drugačiji ishod pretpostavljalo bi ne računati više na pravila igre koja dati horizont, od kojeg se pokušava načiniti otklon, ostvaruje. To bi podrazumevalo i uvid da su kategorije poput suštine, svrhe ili istine zavisne od pojedinog narativnog sklopa, koji na njima svojim pričama u većoj ili manjoj meri insistira. Istina jedne priče ili pripovesne skupine može biti laž druge, i obrnuto. Pravila igre različitih igara i dobijeni rezultati ne mogu imati transnarativna važenja, usled proste činjenice da se radi o različitim igrama, ukoliko se o njima uopšte radi, jer pretpostavka igranja takođe ne bi trebalo da bude hipostazirana. Neki narativi svoj unutrašnji rad nikada ne bi nazvali tako, niti bi se postavljali prema sopstvenim proizvodima kao prema produktima ludičkog karaktera jezika. Iz tog razloga možemo reći da je narativima samo naprosto ponuđeno to da vlastite izraze tumače kao apsolutne istine, ili pak da poriču postojanje tih istina. Međutim, takođe im je ponuđeno da pripovedaju o tome kako je svaki kriterijum istine dat unutar određenog narativnog horizonta, tako da bi svaka intervencija druge pripovesti, koja bi naprosto izjavila, recimo, da te konkretne istine „nema“, mogla biti načinjena samo unutar te druge pripovesne skupine, jednako nepoopštive i kontingentne kao i prve. Ukratko, određene istine ,ima“ ili „nema“, u zavisnosti od vrlo konkretne priče ili narativnog horizonta, koji to na takav način tematizuje. „Apsolutni kriterijum“ za proglašavanje postojanja ili nepostojanja bilo činjenica, svrha, suština, istina, ili bilo čega drugog, takođe je omogućila samo neka određena priča ili pripovesna mreža - odnosno, možda njena sama stvar. Ona je prožimanje stvarnosti i individualiteta, njihovo jedinstvo, koji su svi skupa narativi i pripovesno-jezički pruženi. Sama stvar je čisto (narativno) tvorenje uopšte, a time i tvorenje individuuma, itd.: „Dakle, u samoj stvari kao predmetno postalom prožimanju individualiteta $i$ predmetnosti, za samosvest je nastao njen pravi pojam o sebi, ili ona je došla do svesti o svojoj supstanciji““. ${ }^{39}$

${ }^{39}$ Ibid., str. 241. 


\section{UZAJAMNA OBMANA I DUHOVNA SUPSTANCIJA}

Priča je za nas, u ovom njenom momentu, nešto „postvareno“, „rađeno“, već „tvoreno“: ne zavisi ni od kakve „želje“, „svesti“, „same stvari“, „svrhe“ jezičkog događanja, već se ti navedeni temati moraju uvek razumevati iz date pripovesti, koja je pak jedina u stanju da načini ovakve diferencijacije, kao različite trenutke koji tvrde/pripovedaju nešto drugo do onoga kako ih neka drugačija priča može jezički izlagati. „Argumentacija je uvek već neka naracija“ - to donosi priča filozofije priča. Zajedno sa Hegelom bi se stoga trebalo pitati o tome kako to tvorevina tvrdi nešto o svom realitetu i marenju, kako i čime pokazuje jedinstvo odluke i realiteta, ili kako pronalazi zadovoljstvo u iščezavanju svoje stvarnosti? Kako stvarnost tvorevine uopšte iščezava? Ovim pitanjima i zahtevanim odgovorima uvek biva opozvan neki narativ da odgovori, da pruži određeno svedočanstvo, čija se „ispravnost“, kao, uostalom, i eventualne ,pogrešne postavke“ i odgovori, pronalaze samo u pričama i konstelacijama koje su u stanju ta pitanja i odgovore na prvom mestu da ponude. Drugim rečima, datih pitanja i mogućih odgovora ima samo zahvaljujući ovom konkretnom Hegelovom narativu, koji pak, sa svoje strane, donekle odslikava i upućuje baš na ovu dinamiku, koja je blisko vezana za igru smenjivanja koju narativi ovde prepoznaju - igru tvorenja, iščezavanja tvorenja, kontingencije stvarnosti koja predstavlja samo jedan momenat, i to onaj koji se sa tvorenjem, koje je za nas uvek narativno, suštinski izjednačava:

„Pošto ono što je opšte sadrži pod sobom ono što je negativno ili iščezavanje, to spada u tvorenje svesti i to što se tvorevina poništava; ona je na to podsticala druge, i u iščezavanju svoje stvarnosti nalazi zadovoljstvo, kao što rđavi mladići u šamaru koji dobijaju uživaju sami sebe, naime kao njegov uzrok. Ili, ona čak nije ni pokušala da samu stvar izvede niti je išta tvorila, onda ona to nije marila; sama stvar je za nju upravo jedinstvo njene odluke i realiteta; ona tvrdi da stvarnost nije ništa drugo do njeno marenje“، ${ }^{40}$

${ }^{40}$ Ibid., str. 242-243. 
„Poništavanje tvorevine“, na tragu onog negativnog i iščezavanja, mi u prvom redu razumemo kao stajanje priče ili pripovesne konstelacije na raspolaganju - ali ne nekoj svesti koja svoj individualitet u bilo kom trenutku može da gradi na fenomenu sećanja, te eventualnih preplitanja tih iskustava, sada označenih kao ,prošlih“, sa nekim realitetom i stvarnošću kojoj se svest neprestano izlaže. Priče stoje na raspolaganju samo drugim pričama(-)jeziku. Ova priča o filozofiji priča upućuje na to da se sećanje, kao iskustvo onoga što se podvodi pod ,prošlo“ ne može na takav način odvojiti od neke „stvarnosti“, shvaćene kao datost i puka prezentnost. Stvarnost i sećanja su uvek ništa drugo do pripovesna događanja. Primerice, Avgustinov verbum interius, unutrašnja reč, takođe je moguća ne kao momenat svesti i nekog svesnog procesa, već kao narativ. Zbog toga ne možemo govoriti ni o strogoj diferenciji npr. poništavanja (tvorevine), kao ni njene kreacije koja bi pretpostavljala određeno uprisutnjenje. Priča nikada nije do kraja poništena, ona ne može naprosto nestati, iako se ona možda trenutno ne nalazi u krupnom kadru tekuće priče. To što priče ne mogu da nestanu, budu do kraja „zaboravljene“ ili na bilo koji drugi način poništene, još jedan je od pokazatelja čistog mnoštva priča. Rad jezika je uvek narativ, što ne znači da on ne može izgubiti iz vida tu dimenziju. Ukoliko ima delanja, ono je narativno i nikakav rad se ne može pronaći izvan pripovesti, samim tim što je svako događanje fundamentalno jezičko-narativno.

Da se Hegel može uzeti kao da je na sličnom tragu pokazivanja ove poteškoće da se sa sigurnošću razluči između onoga što bi se moglo nazvati ,idejom“ neke tvorevine i onoga što bi se vulgarno moglo nazvati „sprovođenjem u delo“, govori nam i segment u kom za tvorenje „stvarnost“ predstavlja i sam čin „marenja“, koji ovde uzimamo nikako drugačije nego kao manifestovanje priče. Ona se, bivajući jednaka sa tvorenjem, s obzirom da je rad jezika uvek pripovesna tvorevina, ne može na bilo koji način dovoditi u odnos sa nečim što se kratkovido naziva samostalnim „realitetom“, nezavisnom „stvarnošću“, itd.

„Naposletku je postalo nešto što je za nju interesantno uopšte bez njenog sadejstva, onda je ta stvarnost za nju sama stvar upravo u tome interesu koji ona u njoj nalazi, mada je nije ona proizvela; ako je to neka sreća koju ona lično doživljuje, onda se ona nje pridržava kao 
svoga dela i zasluge; ako je to inače neki svetski događaj koji se nje ništa ne tiče, onda ga ona isto tako prisvaja, i pasivno interesovanje smatra za zalaganje koje je ona preuzimala u prilog tog svetskog događaja ili protiv njega, i koji je pobijala ili podržavala“. 41

Navedeno može biti sasvim validno, te u potpunosti saglasno i razumljeno kroz priču o stapanju narativa. Može delovati na prvi pogled da se ne ostavlja ipak previše prostora za to da ovaj segment bude označen kao suštinski inspirativan za nas ovde. Ali, i te kako se na osnovu toga može rekonstruisati način na koji se priče ograđuju ili prihvataju zasluge za dalja postvarenja narativnih tokova, u zavisnosti od toga kako njih same i u kakvom svetlu nadolazeći narativi uzimaju: neki narativi će možda zahtevati priznavanje direktnih uzročno-posledičnih veza, dok će drugi poricati bilo kakav stepen umešanosti. Sve to, dakako, pokazuje krajnju fluidnost priča, koje se nikada ne ponavljaju kao iste. Hegelovo „čisto tvorenje“ sada možemo uporediti sa „čistim naracijama“: „Čisto tvorenje je u suštini tvorenje ovoga individuuma, i to tvorenje je isto tako u suštini jedna stvarnost ili jedna stvar" ${ }^{42}$ Narativna konstelacija je zaslužna za tvorenje svakog vida ove stvarnosti, ,postvarenosti“ koja se pripisuje jeziku, ukoliko priča. A ukoliko je jezik, utoliko nužno i priča. Priče na suštinski sličan način polažu račun i o uobrazilji, stvarnosti, obmani, istini, svrhama, suštinama, itd.:

„Dakle, pošto je tome individuumu, kako izgleda, stalo jedino do same stvari kao apstraktne stvarnosti, to postoji takođe i to, da je njemu stalo do nje kao svoga tvorenja. Ali isto tako, pošto je njemu stalo samo do rada i tvorenja, to on taj rad i tvorenje ne uzima ozbiljno, već je njemu stalo do neke stvari i do te stvari kao svoje. Naposletku, pošto on, kako izgleda, želi samo svoju stvar i svoje tvorenje, to je opet stalo do stvari uopšte ili do stvarnosti koja ostaje po sebi i za sebe“". ${ }^{43}$

Ova svojevrsna „egocentričnost" nije karakteristika nekakve subjektivnosti, već priča, koje samim činom svoga proizvođenja i

\footnotetext{
${ }^{41}$ Ibid., str. 243.

${ }^{42}$ Ibid.

${ }^{43}$ Ibid., str. 243-244.
} 
postojanja mogu biti uzete tako da se njihova dalja predaja tumači kao izraz želje za njenim konstantnim tokom i daljim generisanjem. Ali moramo prihvatiti $\mathrm{i}$ to da ovakvo tumačenje ne nudi ništa drugo do narativ, što samo pokazuje to da se na ovaj način ne može postulirati i pokazati nekakva temeljna karakteristika. Ona uvek pokazuje da bilo kakva krajnja određenja mogu biti shvaćena samo kao jezički izrazi date priče. Određeni narativi, na osnovu puke navike, pokazuju tendenciju da govore na ovakve načine, katkad ne uvažavajući i ne mareći pritom za vlastitu kontingenciju.

Interakcije pripovesnih čvorišta, narativa, izgledaju, između ostalog i ovako: „Dakle, jedan individualitet smera nešto da izvede; time je on, kako izgleda, nešto pretvorio u stvar [... $]^{\text {“44 }}-\mathrm{u}$ ovom slučaju, to znači da je pričajući, pripovest sebe izložila određenim narativnim čvorištem; , ,[...] on radi, u tome radu postaje za druge $[\ldots]]^{\star 4}, 45$ to jest, biva prepušten drugim narativnim čvorištima i mnoštvima njenih priča; ,[...] i izgleda da je njemu stalo do stvarnosti [...]", 46 odnosno, narativu je „stalo“ do „sebe samog“, tj. do priče koja dalje ponavlja narative dominantne pripovesne konstelacije - a to je ništa drugo do izraz svojevrsnog „preslišavanja“ datog narativnog horizonta, kroz priče koje nikada nisu iste, s obzirom da je svako ponavljanje (priče) jedino ponavljanje razlike. „Drugi, dakle, individualiteti uzimaju njegovo tvorenje $[\ldots]^{\text {“ }}{ }^{47}$ to jest, priče interaguju iz čistog mnoštva, neprestano ga proširujući; a za ta mnoštva se stoga može reći da ih je „uvek bilo“ (iako i tu odrednicu treba uzeti sa krajnjom rezervom, jer i ona biva ostvarena nekom pričom, koja je uslov mogućnosti tog ostvarenja), jer su jezik()priče uvek u neprestanim dijaloškim odnošenjima kao primopredajama, što znači da ne možemo govoriti o jednoj priči kao prvotnoj, primordijalnoj; ,[...] za neko interesovanje za stvar kao takvu i za

\footnotetext{
${ }^{44}$ Ibid., str. 244.

${ }^{45}$ Ibid.

46 Ibid.

${ }^{47}$ Ibid.
} 
njegovu svrhu, da stvar bude izvedena po sebi, svejedno da li je izveo prvi individualitet ili su to oni učinili““. ${ }^{48}$

U pokušaju opisa tih međusobnih nadopuna i primopredaja, koje vrše narativi, moguće je, na Hegelovom tragu, uočiti i to kako narativi neretko pokazuju ovu tendenciju da budu priznati i prepoznati kao nešto drugo do - narativi:

„Pošto oni nakon toga pokazuju da su tu stvar oni već proizveli ili, ako ne, oni nude svoju pomoć $\mathrm{i}$ čine je, to je ona svest naprotiv izašla odatle gde su mislili da se ona nalazi; ono što svest kod stvari interesuje jeste njeno delanje i tvorenje, te, primetivši da je to njeno delanje i tvorenje bilo sama stvar, oni se dakle osećaju obmanuti. - Ali njihovo pritrčavanje u pomoć nije u stvari bilo ništa drugo do namera da vide i pokažu svoje delanje, a ne samu stvar, to jest oni su hteli da u tome obmanu druge upravo na isti način na koji su oni sami, prema svome zaklinjanju, obmanuti“ “ ${ }^{49}$

Više nego uočljivo je do sada da ovde sve vreme pokušavamo da idemo u nekim drugim smerovima, od onih uobičajenih, gde rizikujemo da ovo čitanje bude označeno da prolazi „mimo Hegela“, ili čak da ide kontra njegovim usmerenjima. Međutim, ovde, između ostalog, pokušavamo da demonstriramo i to da je taj rizik samo procena nekog pojedinačnog narativa, ili narativne skupine koja ne može pretendovati na to da uspostavlja apsolutni kriterijum u razmatranju i procenjivanju vrednosti drugih narativa i načina njihovih interakcija. Ta vrsta pokušaja monologizma, homofonije nekog narativa ili konstelacije, koja pokušava da stoji nezavisno i zatvorena sama u sebi, uvek je u koliziji sa čistim pripovesnim mnoštvom, koje je neprestani disruptivni faktor ovoj svojevrsnoj ksenofobiji. Kod samog Hegela, uostalom, kao što je ovde više puta pokazano, može se uočiti ova naznaka polifonije i mnoštvenosti, tj. nemogućnosti upravo ovih podvajanja između neke „prave“ i „neprave“ (narativne) tvorevine. Priče katkad teže ovom poopštenju i poopštivosti, uprkos tome što su one (uvek) partikularne i kontingentne:

\footnotetext{
${ }^{48}$ Ibid.

${ }^{49}$ Ibid., str. 244-245.
} 
„Oni izdaju svoje delanje i tvorenje za nešto što postoji samo za njih same, u čemu oni imaju u vidu jedino sebe i svoje vlastito suštastvo. Ali time što nešto tvore i time izlažu sebe i pokazuju se svetlosti dana, oni delom protivreče neposredno svome tvrđenju da žele da isključe samo svetlo dana, opštu svest i učešće sviju; ostvarenje je naprotiv izlaganje onoga što je svoje u opšte elemente, usled čega ono postaje i treba da postane stvar sviju“. ${ }^{50}$

To da ,postane stvar sviju“ možemo tumačiti kao insistiranje na značaju prepoznavanja čistog mnoštva priča. Kao nadopunu prethodnom može pružiti i ova sjajno opisana nemogućnost izvođenja i instituisanja jedne priče, čiji narativ bi bio u stanju da uguši glasove drugih, kao i da se sa druge strane otrgne igri partikularnosti, poopštivosti, kontingencije i nužnosti:

„Dakle, ako treba da je stalo samo do čiste stvari, onda je to isto tako obmana sama sebe i drugih; svaka svest, koja jednu stvar podiže, ima štaviše iskustvo da drugi, želeći da se smatraju pri tome poslu zaposlenima, žurno pridolaze, kao što muve sletaju na sveže mleko, i oni na toj svesti doživljuju da njoj isto tako nije stalo do stvari kao predmeta, već da joj je do nje stalo kao do svoje stvari ““. ${ }^{51}$

Priče su, bivajući radom jezika, tu za (uvek) druge priče. Narativna čvorišta reflektuju priče, koje nisu ni u kom pogledu „njihove“, jer ni narativne konstelacije nisu od tih čvorišta na bilo koji način odvojene: ako nečega ima, onda je to čisto mnoštvo pripovesti:

„Usled toga sama stvar gubi odnos predikata i određenost beživotne apstraktne opštosti, ona je naprotiv supstancija koju prožima individualitet: onaj subjekat $\mathrm{u}$ kojem se nalazi individualitet isto tako kao sama ta stvar ili u kojem se ovaj individualitet nalazi onako kao sve individue, i ono opšte koje samo kao to tvorenje sviju i svakoga jeste jedno biće, jedna stvarnost po tome što ova svest zna za nju kao za svoju pojedinačnu stvarnost i kao za stvarnost sviju““. ${ }^{52}$

\footnotetext{
${ }^{50}$ Ibid., str. 245.

${ }^{51}$ Ibid., str. 245-246. „Svest“ je i ovde uzeta kao „,narativno čvorište“.

${ }^{52}$ Ibid., str. 246.
} 
Priča je ta koja vrši sva ova nazivanja: „Čista stvar jeste što je gore određeno kao kategorija: biće koje jeste Ja, ili Ja koje jeste biće, ali kao mišljenje koje se još razlikuje od stvarne samosvesti; ovde pak momenti stvarne samosvesti, ukoliko ih nazivamo njenom sadržinom, svrhom, tvorenjem i stvarnošću, kao i ukoliko ih nazivamo njenom formom, bićem za sebe i bićem za drugo, jesu postavljeni sa prostom kategorijom kao jedno isto, i usled toga kategorija je u isto vreme sva sadržina“". ${ }^{33}$

\section{ZAKLJUČNA RAZMATRANJA}

Što se tiče „originalne prirode“ individuuma, uviđa se njena konačna neuhvatljivost. Individuum je ostvaren prvenstveno kroz njegovo delanje. Dinamika delanja, koju Hegel pokazuje, upućuje na uvid koji je svest napravila o svojoj konačnoj neodeljenosti od spoljašnjeg sveta (identitet subjekta i objekta). Samo-izvesnost je odavno prevaziđeni stadijum u napretku ka apsolutnom znanju, te svest sebe shvata kao onu koja pokušava da načini uticaj na druge kroz svoju delatnost, prihvatajući nužni etički momenat, na svom pomenutom razvojnom putu ka apsolutnom znanju:

„Oni izdaju svoje delanje i tvorenje za nešto što postoji samo za njih same, u čemu oni imaju u vidu jedino sebe i svoje vlastito suštastvo. Ali time što nešto tvore i time izlažu sebe i pokazuju se svetlosti dana, oni delom protivreče neposredno svome tvrđenju da žele da isključe samo svetlo dana, opštu svest i učešće sviju; ostvarenje je naprotiv izlaganje onoga što je svoje u opšte elemente, usled čega ono postaje i treba da postane stvar sviju“. .54

Sa naše strane je očekivano da čitavo ovo narativno izlaganje mora prvenstveno biti stavljeno pod lupu, tj. tretirano metodom naracije, koji bi ovu konkretnu pripovest, kao i svaku drugu, podsetio svog narativnog karaktera i time „vratio“ u onaj jezik(-)priču koja pokazuje svako događanje kao čisto pripovesno mnoštvo. Međutim, priči o

\footnotetext{
53 Ibid.

${ }^{54}$ Ibid., str. 245.
} 
filozofiji priča je ponuđeno i to da se na ovome ne zaustavi, već eventualno pokaže i to da ovaj narativ takođe može biti dalje iskorišćen i predat radu (filozofije) priča. Naime, originalna priroda individuuma biva suštinski ugrožena radom, te pada u potpunosti u drugi plan, s obzirom da delanje individuuma postaje na neki način sada određujuće, determinišuće za taj konkretni individuum. To znači samo da priče, koje neko narativno čvorište smatra konstitutivnim za „nju/njega“, iščezavaju u pozadini. Ali, i pomenuto smatranje je takođe narativno, jer nijednog identiteta nema bez pripovesti koja ga kao takvog konkretnog donosi. Delanje, rad indvidiuuma, u ovom smislu, rezultuje u otuđenju onda kada pripovesno čvorište, kao skupina nekih više ili manje kongruentnih priča, ne uspeva da se odupre onoj narativnoj konstelaciji koja vrši pritisak u pokušaju da u potpunosti asimiluje dato čvorište i zapostavi, zanemari ono što narativno čvorište već aktivno pripoveda, itd. Ipak, od krucijalnog značaja je to da shvatimo da ovi odnosi nisu puke datosti, nešto čiji se narativni tokovi ne mogu izmeniti. Odnos gospodara i roba kod Hegela, ili pak volje za moć kod Ničea, primera radi, dati su samo kao momenti kontingentnih priča. Oni nisu u svim narativnim oblicima i okvirima egzaktni opisi stanja svakog jezičko-pripovesnog rasprostiranja i događanja, iako se očigledno pronalaze određena poklapanja, na osnovu prisutnih, rasprostranjenih narativnih konstelacija - drugačije te priče ne bi ni bile iskristalisane kao relevantne u datim okvirima. To je samo potvrda čistog mnoštva, kao i toga da se konstantno dešavaju međusobna odmeravanja narativa, na način da se mahom održavaju u blizini i ne iščezavaju oni koji svoje sadržaje crpe iz tu prisutnih dominantnih konstelacija i njihovih mreža. Upravo na Hegelovom tragu bismo mogli reći da se najduže održavaju oni narativi koji su postvareni na način da se mogu, pre svega, bezrezervno predati dalje toj, ili nekoj drugoj narativnoj konstelaciji, a istovremeno i čistom narativnom mnoštvu; dok sa druge strane prihvataju igru deskripcije i redeskripcije one konkretne konstelacije koja taj pojedinačni narativ i omogućuje. Ovo „postvarenje“ ne bi trebalo posmatrati kao aktualizovanje nečega „planiranog“ ili „intendiranog“, jer priča uvek jeste - i to jeste za druge priče. Njihova mnoštvenost se očituje u svakom sabranom narativnom čvorištu, tako da za priče shvaćene $u$ ovom smislu nema striktno govoreći sfere privacije, $u$ 
kojem su one „same za sebe“. Zato delatnost, koja je uvek jezičkopripovesna, nije neki izraz individualnosti koja bi stajala negde drugde $u$ odnosu na jezik-pripovest. Negativitet, o kojem Hegel govori, upravo je izraz ove neprestane promene koju jezik(-)priče doživljavaju, bivajući (u) čisto(m) mnoštvo(u), i kao takve uvek predate novim (drugim) pripovesnim slojevima. Ova vrsta negativiteta ne ugrožava stoga neku originalnu prirodu svesti (narativa), pošto nema jedne priče koja određuje šta priče jesu ili nisu, ili šta čini neko narativno čvorište. Šta je više u duhu hegelijanskog narativa do prepoznavanje da takav negativitet ništa ne ugrožava, jer nije puki destabilišući, zloćudni faktor, već deo pripovesne, kontingentne prirode? Ona je opet, sa svoje strane, podložna daljem radu kontingencije i opisanog negativiteta, čije proizvođenje je ponavljanje razlike.

Što se tiče dalje razrade ove dinamike ,planiranog“ $i$ „aktualizovanog“, „postvarene“ i „,nepostvarene“ delatnosti, želje, i dr., koja se kod Hegela neprestano provlači, iz perspektive priča filozofije priča bi trebalo dovesti u pitanje kvalitativne razlike između tih kategorija. Ukoliko je svako događanje fundamentalno jezičko()pripovesno, onda se ne može tako jednostavno održati ni ovaj dominantni vokabular, koji vrši te vrste distinkcija. Priča je uvek delatnost (jezika). Produbljivanje ove problematike od strane Hegela, u temama otuđenja od rada, iz tog razloga se pokazuje kao izlišno. Za njega su iskreni oni koji na otuđenje između svrhe i delanja reaguju tako što alijenaciju odbacuju. Iskrenom svešću se smatra ona koja je u stanju da prihvati neuspeh svog delanja - takav čin donekle rezigniranog priznanja omogućuje toj svesti da pronađe utehu, itd. Sa naše strane, ne bismo mogli reći šta bi bio iskreni narativ, s obzirom da su ,iskrenost“ i „neiskrenost“ omogućeni nekim vrlo konkretnim pričama. Jer, ukoliko bi „iskreni narativ uopšte“ npr. bio onaj koji uviđa i prihvata vlastitu kontingenciju, to u ovoj situaciji podrazumeva i uvid o tome da narativi leže van koordinata uspeha ili neuspeha, jer te kategorije donose takođe neki kontingentni narativi i narativne konstelacije. Sa ovim uvidom narativu tada nije potrebno pronalaženje utehe u tome što je ,imao želju da nešto ostvari“. Međutim, s obzirom da se kod Hegela ova ,iskrenost“ ispostavlja zapravo da je forma „varke“, tj. suštinski „neiskrenost“, time 
što se na neki način zadovoljava vlastitom pozicijom pasivnosti i iluzijom da je učinila „sve što je u njenoj moći“, priča filozofije priča mora intervenisati pokazivanjem ne samo zavisnosti svih ovih pojmova od datog horizonta, već i same stvari, koja za Hegela ujedinjuje svrhu i delanje. Rad je uvek rad mnoštva pripovesti i rezultat tog rada iznova su druge pripovesti, kontingentne i nepoopštive. Sama stvar, zamišljena kao opštost kojoj svako treba da doprinese, mora biti shvaćena najpre kao priča/tema priča, odnosno, može biti razumljena kao narativna konstelacija, horizont priča, koji drži na okupu određeno jezičko proizvođenje, koje sebi postavlja ciljeve, svrhe i procenjuje uspešnost njihovih ispunjenja na osnovu kriterijuma koje je sam, svojim pričama, postavio, ili nastavlja da uspostavlja svojim daljim delatnim proizvođenjem. To je filozofija rada (filozofije) kao priče filozofije priča. Rad filozofije je uvek neki narativ. Kao što svaka priča ne mora biti, niti jeste, filozofska, tako ni svaki rad nije filozofski, iako je jednom filozofijom rada tematizovan. Priča filozofije priča upravo tematizuje ovu filozofiju rada, koja je i filozofija rada filozofije. Svaki rad filozofije je priča (filozofije) - to je u stanju da pokaže priča filozofije rada - ali ona nije nužno ponuđena samo ovom pripovesnom polju i njoj kao disciplini, već takođe mnoštvu priča, koji od nje mogu, tj. uvek sačinjavaju nešto sasvim drugo (drugu priču).

Smatramo da eksperimentalni karakter ovoga rada odslikava i krajnje eksperimentalni karakter filozofije, tendenciju da jezik na sebi interveniše i na načine na koje možda određeni pripovesni horizont ne očekuje, ili barem ne iščekuje, ako/kada ne želi da bude ometen u vlastitoj samodovoljnosti. Međutim, jasno je da jezik(-)priče ne ispunjavaju takve hirove, te da uvek teže da pronađu pukotine kroz koje je bujica narativa u stanju da proizvodi udare i tektonska pomeranja pastoralnog i učmalog narativnog tla, njegovog pretendovanja na monologizam i homofoniju. Ti udari i pomeranja pokazuju upravo suprotno: dijalogizam, polifoniju, čistu narativnu mnoštvenost - kojoj je Hegelov narativ svakako na tragu. 


\section{LITERATURA}

Bakhtin, Mikhail, Problems of Dostoevsky's Poetics, Theory and History of Literature, Volume 8 (ed. and trans. Emerson, C.), University of Minnesota Press, Minneapolis, London, 1999.

Bakhtin, Mikhail, The Dialogic Imagination, University of Texas Press, Austin, 1981. (ed. and trans. Holquist, M., Emerson, C.)

Barthes, Roland, The Rustle of Language, University of California Press, Berkeley and Los Angeles, 1989.

Baugh, Bruce, French Hegel. From Surrealism to Postmodernism, Routledge, London and New York, 2003.

Guerrero, Miguel D., The Academic Animal is Just an Analogy: Against the Restrictive Account of Hegel's 'Spiritual Kingdom', Stance, Volume 9, April 2016.

Hegel, G. V. F., Fenomenologija duha, BIGZ, Beograd, 1986. (prev. Popović, Nikola M.)

Lecercle, Jean-Jacque, Deleuze and Language, Palgrave Macmillan, New York, 2002.

Niče, Fridrih, Knjiga o filozofu (Saznajnoteorijski uvod o istini $i$ laži u izvanmoralnom smislu), Grafos, Beograd, 1987. (prev Aćin, J.)

Pinkard, Terry, Shapes of Active Reason: The Law of the Heart, Retrieved Virtue, and What Really Matters, u: The Blackwell Guide to Hegel's Phenomenology of Spirit (ed. Westphal, Kenneth R.), 2009.

Schapp, Wilhelm, Auf dem Weg einer Philosophie der Geschichten, Verlag Karl Alber, Freiburg/München, 2016. (Hg. Joisten, K., Schapp, J., Thiemer, N.)

Schapp, Wilhelm, In Geschichten Verstrickt. Zum Sein von Mensch und Ding, Vittorio Klostermann GmbH, Frankfurt am Main, 1985. (5. Auflage 2012.)

Schapp, Wilhelm, Philosophie der Geschichten, Vittorio Klostermann, Frankfurt am Main, 2015. (Hg. Joisten, K., Schapp, J.)

Silverman, Hugh J., Inscriptions: After Phenomenology and Structuralism, Northwestern University Press, Evanston, 1997.

Vaihinger, Hans, Die Philosophie des Als-Ob, Verlag von Felix Meiner, Leipzig, 1922.

Vereme, Donald Phillip, Hegel's Recollection: A Study of Images in the Phenomenology of Spirit, State University of New York Press, Albany, 1985. 


\author{
NEMANJA MIĆIĆ \\ University of Novi Sad, Faculty of Philosophy
}

\title{
THE STORY OF THE PHILOSOPHY OF STORIES AS THE PHILOSOPHICAL ACTIVITY AND THE PHILOSOPHY OF (PHILOSOPHICAL) WORK: STUDIES ON NARRATIVE METHOD AS A LINGUISTICAL ACTIVITY IN THE LIGHT OF THE SPIRITUAL ANIMAL KINGDOM FROM HEGEL'S PHENOMENOLOGY OF SPIRIT (PART II)
}

\begin{abstract}
In these studies we will try to take a somewhat different approach, by way of the story of the philosophy of stories, towards a philosophy of (philosophical) work, which can be inferred from the section Spiritual animal kingdom and deceit, or 'the matter in hand' itself, which can be found in Hegel's Phenomenology of Spirit. Instead of following the well-established textual route concerning this matter, which often consists of interpreting this particular Hegel's narrative as the one which describes the traits of intellectual or academic work, or the work in general, we would like at first to present the idea that every activity is fist of all language-based and simultaneously story-driven, as well as the notion that the result of every linguistic activity is always going to be some (contingent) story. These stories actualize themselves only by continuously referring to other stories, in the pure narrative multiplicity, which language manifests fundamentally. If there is any work or activity whatsoever, it is language and narrative-bound. We shall also determine how helpful this Hegel's study and its speculative character could be, in an attempt to elucidate the story of the philosophy of stories as the philosophy of (philosophical) work.
\end{abstract}

Keywords: narrative, story, multiplicity, contingency, work, philosophy, activity, Hegel, Spiritual animal kingdom

Primljeno: 19.2.2019.

Prihvaćeno: 9.5.2019. 